\title{
THE CAT IN MUSIC
}

\section{By CARL VAN VECHTEN}

Vous qui ne sauez pas ce vaut la musique, $V$ enez-vous en ouïr le concert manifique

Et les airs rauissants que iaprens aux Matous.

Puisque ma belle voix ren ces bestes docilles, Je ne scaurois manquer de vous instruire tous

$\mathrm{Ni}$ de vous esclairsir les nottes difficiles.

$I^{\mathrm{N}}$

N "The Question of Our Speech," Mr. Henry James, who is usually precise and careful in his statements of fact, has permitted himself to say, "It is easier to overlook any question of speech than to trouble about it, but then it is also easier to snort or to neigh, to growl or to 'meaow,' than to articulate and intonate." I do not know how difficult it may be to neigh or to growl or even to snort. I have never tried to make any of these sounds but $I$ have no confidence in my power to do so. About "meaowing," however, I am not at all unenlightened and I could assure Mr. James, were he still alive, that the vocalization of a cat is not so simple a matter as he apparently takes it to be in this casual remark. Dupont de Nemours, a student of animals and their peculiarities, declared that, while the dog only used vowel sounds, the cat in her language made use of at least six consonants, $M, N, G, H, V$, and $F$. It seems obvious to me that $\mathbf{P}, \mathrm{S}$, and $\mathrm{T}$, may be added as necessary spitting consonants; the $\mathbf{H}$ is produced, of course, by the rapid expulsion of breath following this very Magyar explosion of expletives, the cat's method of cursing. I have never heard a cat use a $V$, and I would like more information on this point.

Animals, - writes the ingenious de Nemours,- -have very few needs and desires. These needs are imperious and these desires strong. Their expression is therefore marked, but the ideas are not numerous and the dictionary short; the grammar more than simple, very few nouns, nearly twice as many adjectives, the verb nearly always taken for granted; some interjections which, as $M$. de Tracy has very well proved, are entire phrases in a single word: no other parts of discourse.

Whatever else it may be, and whether you like it or not, the cat language is musical; in her conversation, casual or passionate, 
pussy produces tone. Moncrif found her voice "belle et grande." Champfleury counted sixty-three notes in the mewing of cats, although he admitted that it took an accurate ear and a great deal of practise to distinguish them. On the other hand we have the testimony of the Abbé Galiani who could only discern twenty notes in the most elaborate mewing, but he found that these constituted a complete vocabulary, as no cat ever uses the same phrase except to express the same sentiment. Any one who has lived on friendly terms with a cat must be aware of the justness of this opinion. Recall the trill-like purr ending in its chromatic upward run which accompanies amatory emotion in the female, the shrill cry of fright or anger, the wail of hunger, the polite but peremptory request to be let out or in, what Willy calls "the Hymn to the Doorknob," the demand for water, which no adequate auditor will ever confuse with the demand for food, and the quiet purr of contentment, which, of course, is quite different from the kettle-drum purr of violent pleasure. Any one who has lived on amicable terms with a cat will have no difficulty in understanding so much of her language; an interested observer may pick up much more. For instance my Feathers gives vent to what I call her "hunting cry," just before a leap at the window pane after a fly. This sound is sib to the faint creaking of a rusty hinge. A cat, of course, cannot afford to make too many concessions to a human being, but she finds it possible and convenient to know the meaning of a few words like "dinner" and "meat." I can throw these words into the middle of a sentence in conversation in any tone of voice and Feathers will come bounding to the icechest where she knows her meat is kept. The good Abbé distinguished between the male and female voices, the tenor and soprano cats, and he also discovered that two sequestered cats attended to their love making in silence, which naturally led to the deduction that the long notes and growls of the alley fences and roof-tops were rather calls to the foe, jealousies, bickerings, alarums and excursions, than amorous cries. Others say that the gelded cat has a special cry which gives him a place alongside the male sopranos of the eighteenth century.

A thousand years or so before Christ, the Egyptians associated the cat with music, utilizing the graceful head and figure of the beloved animal in the decoration of sistra. The sistrum consisted of a frame of bronze or brass, into which three or four metal bars were loosely inserted, so as to produce a jingling noise when the instrument was shaken. Occasionally a few metal rings were strung on the bars to increase the sound and very often the 
top of the frame was ornamented with the figure of a cat. The instrument was used by women in religious performances and its Egyptian name, Carl Engel tells us, in "The Music of the Most Ancient Nations," was seshesh. F. A. Paradis de Moncrif in "Les Chats" (Paris, 1727) offers his readers a curious engraving of several of these sistra on which cats are carved in various charming attitudes. There is another engraving in this book of a statue of the cat-god holding the sistrum in such a manner that he shows that he knows how to use it. "Why does not this prove a connection between instruments of music and cats?" asks Moncrif. "The organization of cats is musical; they are capable of giving many modulations to their voices and in the different passions which occupy them they use diverse tones." The discovery of a fresco depicting a cat sitting calmly in the presence of a sistrum and a goblet led Moncrif into further semi-humorous dissertation which is worthy of reproduction if for nothing else than the stupendously enlightened theory of musical criticism which it introduces. This theory, exploited as it was in a "gravement frivole" book on cats, published in 1727, was probably not taken very seriously by Moncrif's contemporaries; there is no reason to believe, indeed, that it was taken very seriously by Moncrif himself, but it was to pop up again two hundred years later as one of the principal tenets of a certain school. The combination of cat, sistrum, and goblet, Moncrif takes as proof that cats were admitted to Egyptian banquets and that they frequently sang there:

Doubtless, he continues, the enemies of cats will insist that cats cannot sing, they can only caterwaul. We will content ourselves by retorting that what seems to be mewing in the cats of to-day proves nothing regarding the cats of antiquity, arts being subject to great revolutions; we add, with all possible discretion, that the dissonances of which these enemies complain, only indicate a lack of knowledge and taste on their part. . . . Modern music is limited to a certain division of sounds which we call tones and semitones and we ourselves are limited enough to believe that this same division is all that can be called music; therefore we have the injustice to exclude bellowing, mewing, whinneying sounds of which the intervals and the relations, perhaps admirable of their kind, are beyond our understanding, because they go beyond the limits in which we are restrained. The Egyptians, no doubt, were more enlightened; they had really studied the music of animals; they knew that a sound can neither be true nor false, and that nearly always it appears to be either one or the other only because we have the habit of judging an assemblage of sounds immediately as harmony or dissonance; they knew, for example, whether the cat used our scale or whether she availed herself of the tones between the half tones, which would make a 
prodigious difference between their music and ours; they appreciated in a chorus of toms, or in a recitative, the simple or more perverted modulation, the lightness of the passages, the softness of the sounds or their piercing quality, from which, perhaps, they derived their pleasure. That this music seems to us a confused sound, a charivari, is only the effect of our ignorance, a lack of delicacy in our organs, of justice, and discernment. The music of the peoples of Asia appears to us at least ridiculous. On their side they find no common sense in ours. We believe reciprocally to hear only mewing; thus each nation is, so to speak, the cat to the other!

Nearly a hundred years ago William Gardiner published a curious book entitled "The Music of Nature" in which it was evidently the author's intention to prove that the sounds of art are derived from the sounds of nature. The book is provided with many tables of examples which Mr. Gardiner has taken down in barnyard and forest, and two examples of cat cries are given. These, however, are not very convincing as they are necessarily expressed in the tempered scale. Any one who has listened to a cat practising vocalises will have no doubt that Moncrif is quite correct in assuming that the animal makes use of smaller divisions than semitones.

So early as the sixteenth century we have a record of the cat appearing in a musical capacity in Europe, strangely enough, however, as part of an instrument and not as a voluntary vocal performer. When the King of Spain, Philip II, went to Brussels in 1549 to visit his father, the emperor, among other festivities a most singular procession was arranged in his honor. At its head marched an enormous bull balancing a tiny devil between his horns, from which shot fireworks. Other quaint conceits were a young boy sewed in a bear's skin seated on a prancing horse, the ears and tail of which had been cut, and the Archangel Saint Michael in gold and purple robes, holding a balance in his hand. But the most curious detail of this mad procession, and the one which awoke laughter from the usually melancholy Philip II, was a chariot on which a bear played the organ. In place of pipes twenty small boxes each held a cat; the protruding tails were bound to the keys of the clavier by cords so that it was only necessary to press one of these keys to produce an "infernal gallemaufry o' din." The naive chronicler of this affair, Juan Christoval Calvete, adds that the cats were arranged in such a manner as to produce the succession of the notes of the scale, but this would have been impossible as no cat was ever limited to a monotone. The cat organ seems to have been comparatively common in the sixteenth and seventeenth centuries, and even as 
late as the eighteenth, for Weckerlin says that records have been found indicating that the instrument existed in Saint-Germain in 1753 and in Prague in 1773. Champfleury describes Father Kircher's still more barbarous variation in which the touch of the keys drove pointed barbs into the cats at the bases of their tails. This almost reads like the experiments Professor Mantegazza describes so merrily in his "Fisiologia del Dolore." Weckerlin in "Musiciana" reproduces an old engraving of a cat organ. A gay rogue with one leg plays the instrument of torture while dogs, monkeys, asses, and cows form a choir. Champfleury found an old picture of the cat organ in Gaspard Schott's "Magia universalis" (1657) and he has reproduced this in "Les Chats."

In Champfleury's book you will also find a copy of a quaint eighteenth century woodcut of an animal tamer, carrying cats on his head and shoulders while on the table before him five cats play the viol, the bass, and the mandoline and still others seem to be singing "miaou," written on the sheets of music before them. At the top of this poster in large letters is written "La Musique des Chats," and underneath on a phylactery, "Ceans lon prend pensionaires et le maistre va monstrer en ville." Other seventeenth century posters remain to prove that mountebanks gave concerts of cats at fairs. Valmont de Bomare describes, in his "Dictionnaire raisonné d'histoire naturelle" (Fourth edition, 1800), a booth at the Fair of Saint-Germain over which had been inscribed the single word, "Miaulique." In the interior some cats sat on a table before a piece of music and at a signal given by a monkey they negotiated feline melodies and harmonies. The whole proceeding seems a perfect symbol for the chef d'orchestre and the prime donne at the opera. In 1758 an animal trainer named Bisset gave what he actually called a "Cats' Opera" in a room near the Haymarket in London.

Other early engravings are more fantastic and less significant of cruelty. A common one shows us a dozen cats, angoras, toms, blacks and whites, seated before a music desk on which the Solfege of Italy in oblong form lies open. The notes, however, are replaced by mice, their tails indicating the crotchets and quavers! Teniers drew a similar scene but added an owl as director and a monkey flute player. In Andrew Lang's version of "The White Cat" in "The Blue Fairy Book" the Prince visits a luxurious apartment

upon the walls of which were painted the histories of Puss in Boots and a number of other famous cats. The table was laid for supper. . . when suddenly in came about a dozen cats, carrying guitars and rolls of music, 
who took their places at one end of the room, and, under the direction of a cat who beat time with a roll of paper, began to mew in every imaginable key, and to draw their claws across the strings of the guitars, making the strangest kind of music that could be heard. The Prince hastily stopped up his ears; but even then the sight of these comical musicians sent him into fits of laughter.

Even in nursery rhymes the cat has standing as a virtuoso. One of the most familiar speaks of "the cat and the fiddle." J. $O$. Halliwell in "The Nursery Rhymes of England" (1844) gives:

A cat came fiddling out of a barn,

With a pair of bag-pipes under her arm.

This musical feat would be beyond the powers of Mischa Elman or Efrem Zimbalist but puss's vocal achievements seem to have been meagre:

She could sing nothing but 'Fiddle cum fee,

The mouse has married the humble-bee.'

With so many examples before them it does not seem unnatural that composers should have begun to imitate the sounds made by cats. Both in Germany and Italy, in the seventeenth century, there was produced a great deal of burlesque imitative music: the cackling of hens all on one note, ending with a fifth above, the mewing of rival toms in nice chromatic order with a staccato, of course, by way of a spit, were favorite pastimes of the severest German contrapuntists. Even the great Marcello has left two elaborate choruses, one for sopranos, the other for contraltos, who are asked to baa like sheep and mou like oxen. Frederic Niecks in "Programme Music" gives us several examples in which the cat appeared. Adriano Banchieri in his carnival farce in madrigal form (1608), has a "contrapunto bestiale alla mente" (an improvised bestial counterpoint), where above the fundamental bass melody, a dog, a cuckoo, a cat, and an owl, barks ("babbau"), calls ("cuccu") mews ("gnao"), and cries ("chiu"). . . Adam Krieger (1667) composed a four-part vocal fugue in which a characteristic chromatic subject is sung to "miau, miau." An instrumental example also dates from this period, the Capriccio stravagante (1627) by the Italian, Carlo Farina, court violinist at Dresden, with its imitations of the cackling of hens, barking of dogs, mewing of cats, etc.

W. F. Apthorp says that when he was looking over the score of a new symphony (name not given) at rehearsal with Otto Dresel, the latter remarked, "Miaou! Miaou! we shall have to get another mise en scène for the concert; we ought to have a roof, 
with a ridgepole and some chimneys." So is poor pussy's voice held in disrepute. However there are examples of cat programme music even in the nineteenth and twentieth centuries. There is, for instance, the spirited dialogue between Puss in Boots and the White Cat in the last act of Tschaikovsky's ballet, La Belle au Bois Dormant, in which the dancers simulate a lively scene between two cats and the orchestra imitates the sounds made by the animals, including, of course, a realistic spit. G. Berthold's Duet for Two Cats seems to have enjoyed considerable popularity although $I$ have never heard it sung. The single word "miau" is vocalized by two singers to runs and scales which are sufficiently catlike to be amusing. In 1917 Igor Stravinsky's Berceuses du Chat for a woman's voice and three clarinets were published. These are four short songs, on popular Rlissian texts, which have been translated into French by C. F. Ramuz. The titles are Sur le poêle, Intérieur, Dodo, Ce quili a le chat. They are evidently written by a lover of cats and they undoubtedly give one the feeling of cats but imitation in music is no specialty of Stravinsky and except in the first song, in which one of the clarinets purrs, there is very little attempt made to transfer the vocal apparatus of the cat into the range of art music. They are strange, exotic, curious little sketches and in hearing Eva Gauthier sing them I was reminded of a passage in Algernon Blackwood's "Ancient Sorceries," the passage in which Vezin listens to the invisible out-door orchestra in the enchanted town he visits unwittingly:

He recognised nothing that they played, and $i_{t}^{t}$ sounded as though they were simply improvising without a conductor. No definitely marked time ran through the pieces, which ended and began oddly after the fashion of wind through an Eolian harp. . . . There was a certain queer sense of bewitchment in it all. The music seemed to him oddly unartificial. It made him think of trees swept by the wind, of night breezes singing among wires and chimney-stacks, or in the rigging of invisible ships; or and the simile leaped up in his thoughts with a sudden sharpness of suggestion-a chorus of animals, of wild creatures, somewhere in desolate places of the world, crying and singing as animals will, to the moon. He could fancy he heard the wailing, half-human cries of cats upon the tiles at night, rising and falling with weird intervals of sound, and this music, muffled by distance and the trees, made him think of a queer company of these creatures on some roof far away in the sky, uttering their solemn music to one another and the moon in chorus.

It was, he felt at the time, a singular image to occur to him, yet it expressed his sensation pictorially better than anything else. The instruments played such impossibly odd intervals, and the crescendos and diminuendos were so very suggestive of cat-land on the tiles at night, rising swiftly, dropping without warning to deep notes again, and 
all in such strange confusion of discords and accords. But, at the same time a plaintive sweetness resulted on the whole, and the discords of these half-broken instruments were so singular that they did not distress his musical soul like fiddles out of tune.

One must not forget Mortimer Wilson's Funeral of the Calico Cat, which, avows James Huneker, "was quite tiny at the beginning of the music, but grew to monstrous proportions before its interment." There is also Edgar Stillman Kelley's Cheshire Cat from his Alice in Wonderland suite. Tom Dobson wrote a song called The Cat and one of the popular airs of The Tenderfoot concerned a tom. The $M e-o w$ one-step, with its superb matou on the cover and its indications to the orchestra to sing the cat cries at appropriate intervals is a popular example. It will be remembered that a rain of cats saved the day in Hans, the Flute Player and that a cat-o'-nine-tails plays a considerable part in "that infernal nonsense, Pinafore."

There have been musical cats. Gautier's silver-grey Angora, Zizi, was a melomaniac. Gautier describes her as listening to music with sleepy satisfaction and she would often go so far as to pick her way up and down the keys of the open pianoforte. Now my cat, Feathers, has a talent for piano playing. Sometimes she walks sedately from one end of the keyboard to the other, producing an exotic succession of tones; at other times she pounces on a group of keys, making sounds not unallied to those which Leo Ornstein evokes in The Wild Men's Dance. On these occasions she will leap wildly from treble to bass, tearing tone and melody to tatters, trying to paw out the secret of the hidden pussy screams from the mahogany box. She has a particular penchant, after the manner of her race, for music at night and it is no rare thing to awaken at 2 A. M. to hear Feathers attempting Bach fugues. There is at least one legend of a cat who furnished a composer with a theme in this fashion. One of Scarlatti's compositions bears the title The Cat's Fugue (at least in modern editions) and the story goes that a stroll on the keyboard of Scarlatti's cat gave the master the subject of the fugue which is as follows:

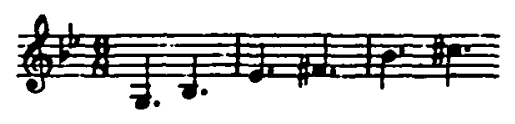

The composition has always been popular with pianists and both Liszt, who often performed it, and von Bulow have arranged editions of it. Bulow in his edition suggests that the droll suggestion of the title should not be lost sight of during performance: 
The first three measures present the mechanical promenade of the cat across the keyboard (the theme proper); the following ones exhibit the justificatory touch of the master-hand, thoughtfully arranging the first chaotic "product of Nature." The marks which I have added for the shading-an almost rough forte for the fore-phrase, and a sudden, tranquillizing piano for the after-phrase-will provide, I think, the simplest means for displaying this humorous contrast, a fairly consistent observance of which is to be recommended throughout. advice:

At the climax of the piece von Bullow gives the following

In the succeeding twenty-two measures, up to the $f f(D$ minor), the cat must, so to speak, swell to a tiger-something like the poodle in Faust's study; i. e., in plain prose, there should be a continuous dramatic intensification in the effect. ${ }^{1}$

Sacchini, too, was beholden to cats. He could only compose, he assured his friends, when he was surrounded by them. Their presence inspired his gracious and seductive music. Weckerlin quotes from the strange will of Mademoiselle Dupuy, a celebrated harpist who lived and died during the seventeenth century. She stipulated that no hunchbacks, cripples or blind persons should be permitted to attend her funeral and she left her fortune to her cat. In Moncrif's "Les Chats" there is a delightful engraving showing the cat on the deathbed of his mistress while two attorneys are making out her testament. Mademoiselle Dupuy believed that she owed her skill as a musician to this cat, who sat beside her while she performed, manifesting pleasure or annoyance, accordingly as she played well or ill. Consequently she left him both a town and a country house with sufficient income to keep them up properly. Her relatives, however, succeeded in wresting this bequest away from the unfortunate cat, who probably was not even allowed to be present in court. Other cat wills have been made and broken since that day.

We learn from Heine that Meyerbeer hated cats and Old Fogy tells an apocryphal story of Brahms which is amusing enough to repeat here:

Brahms, so it is said, was an avowed enemy of the feline tribe. Unlike Scarlatti, who was passionately fond of chords of the diminished cats, the phlegmatic Johannes spent much of his time at the window, particularly of moonlit nights, practising counterpoint on the race of cats, the kind that infest backyards of dear old Vienna. Dr. Antonin Dvořák had made his beloved friend and master a present of a peculiar bow and York.

'The Cat's Fugue: edited and fingered by Hans von Bulow; G. Schirmer, New 
arrow, which is used in Bohemia to slay sparrows. In and about Bohemia it is named in the native tongue, 'Slugj hym inye nech.' With this formidable weapon did the composer of orchestral cathedrals spend his leisure moments. Little wonder that Wagner became an anti-vivisectionist, for he, too, had been up in Brahms's backyard, but being nearsighted, usually missed his cat. Because of arduous practice Brahms always contrived to bring down his prey, and then- 0 diabolical device! - after spearing the poor brutes, he reeled them into his room after the manner of a trout fisher. Then $\rightarrow$ so Wagner averred-he eagerly listened to the expiring groans of his victims and carefully jotted down in his note-book their antemortem remarks. Wagner declared that he worked up these piteous utterances into his chamber-music, but then Wagner had never liked Brahms. . . .

\section{Baudelaire once said:}

I love Wagner, but the music I prefer is that of a cat hung by its tail outside of a window, trying to stick to the panes of glass with its claws. There is an odd grating on the glass which $I$ find at the same time strange, irritating, and singularly harmonious.

Of course this was pure imaginative fiction on Baudelaire's part, who was too much attached to pussies to torture them.

Singers have usually been a little sensitive on the subject of cats, for the resemblances between a certain kind of singing and caterwauling are more than casual and in parody, burlesque, and even in criticism the soprano often finds herself side by side with the tom cat. A hundred years or so ago in London there lived a celebrated music-hall singer who was called "Cat Harris" because he burlesqued the singers of the Italian Opera, imitating them in tones of the feline race. In Cassell's "Old and New London" I found the following:

When Foote first opened the Haymarket Theatre, amongst other projects he proposed to entertain the public with imitation of cat-music. For this purpose he engaged a man famous for his skill in mimicking the mewing of the cat. This person was called 'Cat Harris.' As he did not attend the rehearsal of this odd concert, Foote desired Shuter would endeavour to find him out and bring him with him. Shuter was directed to some court in the Minories, where this extraordinary musician lived; but, not being able to find the house, Shuter began a cat solo; upon this the other looked out of the window, and answered him with a cantata of the same sort. 'Come along,' said Shuter; 'I want no better information that you are the man. Foote stays for us; we cannot begin the cat-opera without you.'

W. T. Parke, forty years principal oboe player at Covent Garden Theatre, in his "Memoirs" tells us why Madame Catalani was almost the only great singer of the period with whom he was not acquainted. He had written a song for Miss Feron, which 
she sang at Vauxhall Gardens, called The Romp or the Great Catalani. The song contained an imitation of Catalani in one of her airs and was intended as a compliment to the singer. However, in the recitative which introduced the air, ending with the words, "Great Catalani" it became necessary, in order to make the music accord with the poetry, to repeat a part of the last word so that it read thus, "Great Cat, Great Catalani." The result, we learn, roused Madame Catalani's ire. But Jenny Lind as a child always sang to her cat, of whom she was inordinately fond. "Her favorite seat," her son is quoted as writing in Canon Scott Holland's book, "was in the window of the steward's room, which looked out on the lively street leading up to the church of St. Jacob. Here she sat and sang to the cat; and the people passing in the street used to hear and wonder." Whether Sophie Arnould cared for cats or not I do not know, but in a letter to Bélanger, dated August 2, 1801, she complains that she has not money left to keep one. We learn from J. H. Mapleson's "Memoirs" that Ilma de Murska travelled with a small menagerie including an Angora cat which her monkey tried to kill on one occasion. Marie-Anne de $\mathrm{Ca}$ margo kept white Angora cats with her dogs in her old age. Emmy Destinn is fond of cats, and so, $I$ believe, was Marie Engle. Most singers, however, seem to prefer dogs, whose voices offer no basis for invidious comparison, and who do not object to a life of travel.

There are, on the other hand, many instances recorded of cats who have an antipathy towards music and musicians. Pierquin de Gembloux in his curious "Traité de la folie des animaux" asserts that he has known of cases in which a cat has been thrown into convulsions by the sound of singing. Some cats seem to have a sound taste in such matters, the aforementioned Mademoiselle Dupuy's cat, for example; Jenny Lind's cat, too, probably gave his mistress signs of his interest in proper tone production. Gautier's Madame Théophile, the same delightful puss that had the horrible experience with a talking parrot, was a musical amateur of taste and discretion.

Sitting on a pile of scores she listened attentively and with visible signs of pleasure to singers. But piercing notes made her nervous and at the high $A$ she never failed to close the mouth of the singer with her soft paw. This was an experiment which it amused many to make and which never failed. It was impossible to deceive this cat dilettante on the note in question.

Eva Gauthier has told me of an experience she once had in Paris when she was singing Der Erlkönig in a friend's drawing 
room. As she was singing the cries of the child, suddenly and entirely without warning, for she was unaware of the presence of any animal, a tiny Siamese kitten, a furry ball of lightning, bounded from the next room and sprang at her throat into which he dug his claws. . . In her charmingly personal book, "Les Chats," Madame Jules Michelet gives several examples of cats who were musical amateurs. The most interesting of these, perhaps, is the account which concerns Minette, who listened to her mistress singing old folk-songs of the province where she had lived as a child.

If I sang a simple, uniform air, spun out in a low voice like the humming of a nurse, she kept her place, raising her eyes, a little dreamy, to mine. But if the air was melancholy, if there were tears in my voice, she began to be agitated. Her obvious uneasiness, however, indicated a certain kind of pleasure. If the tone raised and mounted to that accent of acute grief which is precisely the tone of a violin, Minette gave signs of sickly excitement. The Serenade of Schubert, for example, imploring in its restrained passion, slow first, and sombre as a song of night; this prayer which, from the profound bass, rises to ardent supplication, and takes as witness the bird, its sighs, the emotional silence of Nature,-this supreme cry of a wounded heart succeeded in driving Minette beside herself. Never I believe did a woman's soul exhibit greater grief. She sat on my knees, her eyes fastened only to my lips. If I continued, she placed her two paws on my breast, relaxing herself in a nervous swoon. Her voice refound that shivering mew which in the cat says so many things. Her eyes, in spite of the bright light, were dilated, as they are in a state of suffering or apprehension. If I still continued she mounted higher, and, with a firm gesture, entirely human, she applied her two rigid paws to my mouth, she put a seal on my lips.

This little scene of Minette's may have been excusable. Madame Michelet herself admits that she was no musieian; her singing of Schubert lieder may have been more than a feline melomaniac could stand.

Madame Michelet elsewhere in her book educes the interesting theory that while cats are often painfully affected by the sounds of nearby musical instruments, the faint tinkle of music in the distance often gives them a pleasurable sensation, "inspires them with an amiable madness." Dining with some friends one night opposite the Café Turc, in which a ball was being given she was astonished to see nine cats on the roof, directly over the dance hall, nine cats, grey, brown, and black in the soft light of the roof. These cats silently and gravely moved across the sky in some esoteric relation to the music. With arched backs, tails held-high or lopped-off, stiff legs, stretched, steel ham-strings refalling to each measure, they manifested a marvelous precision. Occasion- 
ally when the band played a fast quadrille they leaped about quite insanely. There is in the Capitoline Museum a bas-relief which represents a woman attempting to teach her cat to dance to the music of the lyre. This cat, uninterested in dancing, is about to snap at a young duck.

Another and fearsome link binds the cat to music, the terrible catgut. Swift has this example of weak wit in his "Art of Punning:" "Why are rats and mice so much afraid of bass-viols and fiddles?" "Because they are strung with catgut." And in his verse with the gruesome title, "The Music of the Future,"1 Oliver Herford comments on the matter as follows:

\footnotetext{
The politest musician that ever was seen Was Montague Meyerbeer Mendelssohn Green, So extremely polite he would take off his hat Whenever he happened to meet with a cat.

"It's not that I'm partial to cats," he'd explain; Their music to me is unspeakable pain. There's nothing that causes my flesh so to crawl As when they perform a G-flat caterwaul.
}

Yet I cannot help feeling-in spite of their dinWhen $I$ hear at a concert the first violin Interpret some exquisite thing of my own If it were not for catgut I'd never be known.

And so, when I bow as you see to a cat, It isn't to her that I take off my hat; But to fugues and sonatas that possibly hide Uncomposed in her-well-in her tuneful inside!

Another celebrated writer has alluded to a violinist as a man who "stretches the bowels of a cat over a wooden box and rubs them with the tail of a horse." The truth is, however, that violin strings are not and never have been, so far as is known, fashioned of catgut; they are really made of lambs' intestines. Why they are called catgut is another etymological mystery. 